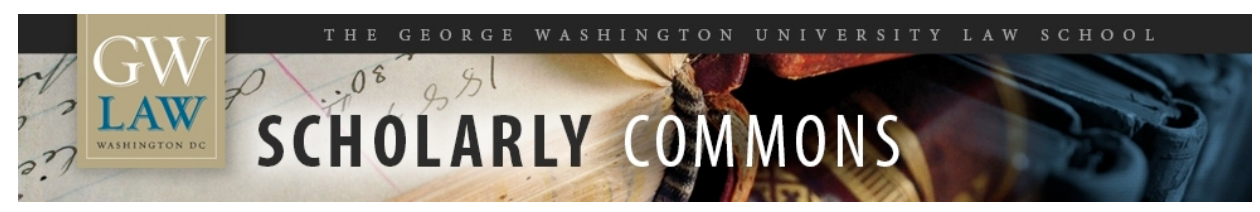

GW Law Faculty Publications \& Other Works

Faculty Scholarship

2006

\title{
Hail, No: Changing the Chief Justice
}

\author{
Edward T. Swaine \\ George Washington University Law School, eswaine@law.gwu.edu
}

Follow this and additional works at: https://scholarship.law.gwu.edu/faculty_publications

Part of the Law Commons

\section{Recommended Citation}

University of Pennsylvania Law Review, Vol. 154, No. 6, 2006

This Article is brought to you for free and open access by the Faculty Scholarship at Scholarly Commons. It has been accepted for inclusion in GW Law Faculty Publications \& Other Works by an authorized administrator of Scholarly Commons. For more information, please contact spagel@law.gwu.edu. 


\title{
Hail, No: Changing the Chief Justice
}

\author{
Edward T. Swaine ${ }^{\dagger}$
}

The trappings of (chief) justice may never have been so alluring. Chief Justice Rehnquist, approaching 20 years in that office, designed for himself spiffy new robes with gold striping - inspired, apparently, by the character of the Lord Chancellor in Iolanthe. ${ }^{1}$ He has admonished advocates who make the mistake of addressing him as "Justice" Rehnquist, ${ }^{2}$ and wrote a letter to caution lawyers against that particular mistake. ${ }^{3}$ Amid talk of Rehnquist's retirement, media reports have speculated whether public appearances by one colleague, Justice Scalia, are actually part of a campaign to improve his chances of succeeding Rehnquist. ${ }^{4}$

All this reflects the importance of the office and the glory of holding it. The chief justice is the highest non-elected position mentioned in the U.S. Constitution, and probably the most important legal job in the land; unlike the Attorney General, who serves at the President's pleasure (as abundantly demonstrated by President Nixon), the chief justice holds office during "good behavior." Life tenure ramps up its appeal considerably. William Howard Taft famously preferred Chief Justice to being President, ${ }^{5}$ and John Quincy Adams noted that while "the power of constructing the law is almost equivalent to the power of enacting it . . . [t]he office of Chief Justice of the Supreme Court is held for life, that of the President of the United States only for four, or at most for eight, years."6

It need not be so, as Rehnquist's robing - in a curious (and rare) nod to comparative constitutionalism - hints. Gilbert and Sullivan's Lord Chancellor claimed to "embody the Law"; his office, indeed, has been the envy of other chief justices. ${ }^{7}$ But the

${ }^{\dagger}$ Associate Professor of Legal Studies, The Wharton School, and Associate Professor of Law, University of Pennsylvania Law School. This essay will be published, in a substantially revised form, in the University of Pennsylvania Law Review, volume 154, number 6. Comments are welcomed.

${ }^{1}$ Richard Lacayo \& Viveca Novak, How Rehnquist Changed America, Time, June 30, 2003, at 20.

2 Tony Mauro, Rehnquist is the Chief, Legal Times, Dec. 3, 1990, at 10 (noting that when an advocate addressed Rehnquist for a second time as "Justice Rehnquist” for a second time, "Rehnquist leaned forward to interrupt and, shaking his finger, reminded [him], 'I am the chief justice.”’).

3 Relationship Among Supreme Court Justices, as Reflected in Justice Blackmun's Notes, Morning Edition (NPR), March 5, 2004 (LEXIS) (remarks of Nina Totenberg).

4 Tony Mauro, Scalia Doll, Legal Times, Apr. 11, 2005, at 11; Margaret Talbot, The Jurisprudence of Justice Scalia, New Yorker, March 28, 2005, at 40.

${ }^{5}$ Alpheus Thomas Mason, The Chief Justice of the United States: Primus Inter Pares, 17 J. Pub. L. 21, 24 (1968); Alpheus Thomas Mason, President by Change, Chief Justice by Choice, ABA Journal, Jan. 1969, at 35; Jeffrey B. Morris, What Heaven Must be Like: William Howard Taft as Chief Justice, 192130, 1983 Yearbook Sup. Ct. Hist. Soc’y 80.

69 Memoirs of John Quincy Adams 250-51 (Charles Francis Adams ed., 1876). Perhaps revealingly, Adams later declined a nomination to become a mere Associate Justice, protesting that he was “conscious of too little law.” Merlo J. Pusey, Court Nominations and Presidential Croneyism, 1981 Yearbook Sup. Ct. Hist. Soc’y 68, 69.

${ }^{7}$ Peter G. Fish, The Office of the Chief Justice 16-17 (1984) (citing remarks by William Howard Taft and Warren E. Burger). Others, though, have expressly rejected the Lord Chancellor as a model, and 
Lord Chancellor has always been subject to change. Traditionally, it was possible for others - including a commoner or a committee - to be assigned some of the Chancellor's duties instead. ${ }^{8}$ The House of Lords has recently thwarted a proposal to abolish the Lord Chancellor's office entirely, ${ }^{9}$ but it remains open for Parliament to transform the position if it chooses.

Just so in the United States. Changing how we appoint the chief justice is a particularly attractive notion. Although the office has always been treated as a separate lifetime appointment, subject to Senate confirmation, that does not seem to be required by the Constitution, and Congress might change things altogether. Picking Chief Justice Rehnquist's successor in a different way - from among the justices, by seniority or by vote of the justices themselves, and for a limited term - might be a modest step toward improving the Court's legitimacy. At the very least, a better understanding our latitude in the appointment process may prompt a clearer evaluation of the present system's costs and benefits.

\section{The Office and its Powers}

The U.S. Constitution only indirectly adverts to a chief justice. Article III provides simply that there will be "one supreme Court" and various "Judges" to populate both it and the lower courts; ${ }^{10}$ Article I, however, mentions the chief justice as the party presiding when the Senate is trying a case of impeachment against the President. ${ }^{11}$ That's it. Section 1 of the Judiciary Act of 1789 amplified that "the supreme court of the United States shall consist of a chief justice and five associate justices"; ${ }^{12}$ one member of the House presciently objected that the title "Chief Justice" was "a concomitant of royalty," but retreated when a colleague pointed out that the term was in the Constitution. ${ }^{13}$

As it develops, the title - and the position - has transcended its constitutional roots. By tradition, the chief justice governs operations at the Court. The chief presides over the Court's public proceedings, governs the agenda and chairs the justices' conferences on case selection and argued cases, and assigns opinions in those cases in which he or she is in the majority. The chief also manages the building and its personnel, and lobbies on the Court's behalf on matters involving its docket and jurisdiction. ${ }^{14}$

criticized what they perceived as a growing resemblance. See especially Phillip B. Kurland, The Lord Chancellor of the United States, 7 Trial 11 (1971).

${ }_{8}$ Technically, the Lord Keeper and the Lord Commissioners of the Great Seal, respectively. Edward Jenks, A Short History of English Law 215-16 ( ${ }^{\text {nd }}$ ed. 1920); e.g., The Lord High Chancellor and the Great Seal, 27 Harv. L. Rev. 70 (1913).

${ }^{9}$ Patrick Wintour, Peers Vote Against Plan to Abolish Lord Chancellor's Traditional Role, The Guardian (London), March 16, 2005, at 8.

${ }^{10}$ U.S. Const. art. III, § 1.

${ }^{11}$ U.S. Const. art. I, § 3, cl. 6.

${ }^{12}$ Judiciary Act of 1789, ch. XX, § 1, 1 Stat. 73 (1789).

131 Annals of Congress 812-13 (Aug. 24, 1789) (remarks of Representatives Burke and Benson).

${ }^{14}$ See generally Fish, The Office of the Chief Justice, supra; Robert J. Steamer, Chief Justice: Leadership and the Supreme Court (1986); Peter G. Fish, Office of the Chief Justice, The Oxford Companion to the Supreme Court of the United States 140 (Kermit L. Hall et al. eds., 1992); Felix Frankfurter, Chief Justices I Have Known, 39 Va. L. Rev. 883, 904 (1953). 
But the position has also developed broader functions, as reflected in its evolving name. While the first chief justices were commissioned as "Chief Justice of the Supreme Court of the United States," presidents and chief justices began to use broader terms like "Lord Chief Justice” and "Chief Justice of the Union," and Congress eventually endorsed their use of "Chief Justice of the United States." 15 The position's national responsibilities grew apace. At Chief Justice Taft's urging, Congress created the Judicial Conference of the United States, chaired by the chief justice, and later the Administrative Office of the United States Courts, which is supervised by the Conference. ${ }^{16}$ The chief has also been made responsible for assigning sitting and retired judges to serve assignments outside of their normal jurisdictions ${ }^{17}$ - which Chief Justice Taft allegedly used to direct judges favoring Prohibition toward "wet” judicial districts, and Chief Justice Burger allegedly used to tilt the Foreign Intelligence Surveillance Court ${ }^{18}$ - and accrued myriad other statutory, legislative, and public relations functions.

The increase in the chief justice's powers has been controversial. The position's diverse responsibilities make it harder to find time for judging, and endanger the Court's perceived independence from politics. ${ }^{19}$ These missions also raise accountability concerns: government officials often accrete powers for their offices, but mission creep is surely more troubling when the powers vest in someone with lifetime tenure.

The point for immediate purposes, however, is that Congress could radically alter this situation. Changing the chief justice's role in presidential impeachment would require constitutional amendment, ${ }^{20}$ but nothing else rises to that level. Many of the chief justice's non-adjudicative functions are of recent vintage, and are if anything weakly

15 John M. Daniel, III, “Chief Justice of the United States”: History and Historiography of the Title, 1983 Yearbook Sup. Ct. Hist. Soc’y 109; Fish, Office, supra note _, at 9-10 (noting “Chief Justice of the Union”); Steamer, supra note __, at 4-5 (noting “Lord Chief Justice”). Chief Justice Salmon P. Chase was a particularly ardent lobbyist for a broader mandate, at the same time urging a reduction in the number of justices so as to increase the salaries for those remaining. Daniel, supra note _, at 111-12. In his view, reportedly, "the Chief Justice was separate and distinct from the court, that, as he stated it, 'the court was built up around the Chief Justice.”” William A. Richardson, Chief Justice of the United States, or Chief Justice of the Supreme Court of the United States?, 49 New Eng. Hist. \& Geneological Reg. 275, 278 (1895).

1628 U.S.C. $\S \S 331.601,621$.

1728 U.S.C. §§ 291-297 (allowing temporary assignment of circuit judges, district court judges, judges of the Court of International Trade, retired justices or judges).

${ }^{18}$ Fish, Office of the Chief Justice, Oxford Companion, supra. Taft himself had urged far greater authority for the Chief Justice, including the power to assign new judges on a permanent basis. See Judith Resnik, Constricting Remedies: The Rehnquist Judiciary, Congress, and Federal Power, 78 Ind. L.J. 223, 277 n.285 (2003). For a terrific analysis of the history and constitutionality of the chief justice's appointment powers, including how it has been exercised in practice, see Theodore W. Ruger, The Judicial Appointment Power of the Chief Justice, 7 U. Pa. J. Constl. L. 341 (2004).

${ }^{19}$ Daniel J. Meador, The Federal Judiciary and its Future Administration, 65 Va. L. Rev. 1031, 1041-45 (1979).

${ }^{20}$ That role has in fact been expanded and contracted without amendment. The Senate rules provide that the Chief Justice shall also take responsibility for presiding over the impeachment of a Vice President serving as acting President. Rules of Procedure and Practice in the Senate When Sitting on Impeachment Trials, If 4, Rules and Manual of the Senate; revised pursuant to S. Res. 479, 99-2, Aug. 16, 1986. On the other hand, Congress by statute provided for an alternative to the Chief Justice. See infra text accompanying notes 
contraindicated by the framers' failure to adopt proposals that would have involved the chief justice in the legislative process. ${ }^{21}$ The chief's responsibilities within the Court may seem worthier of constitutional protection, but the Constitution, recall, only mentions the chief in connection with the Senate, and has left Congress (and, at least in its absence, the Court) free to resolve the chief's more routine adjudicative role. There seems to be nothing that would prevent the other justices, acting singly or collectively, from running the show - a point to bear in mind as we turn to the appointment process.

\section{Appointing the Chief Justice}

Had they been known at the founding, the chief justice's responsibilities might have caused much greater deliberation about the process of appointing one. The records of the drafting and ratification of the Constitution are silent as to what the founding generation contemplated. To be sure, chief judges were scarcely foreign to them. Colonial and state judiciaries provided them with a wealth of experience - for example, half of the first Supreme Court had held analogous office on their states' highest courts ${ }^{22}$ - but it may be doubted whether these variegated schemes cohered or were mastered by any one of them, ${ }^{23}$ and whether they saw much likeness to the Supreme Court they were creating. $^{24}$

If so, three themes might have been apparent. One, concededly, was that the chief justice was widely treated as a separate appointment, hierarchically superior to others of the same tribunal. ${ }^{25}$ Second, the chief's role was often substantively dissimilar to any that might have been contemplated in the U.S. Constitution (for example, because he participated in legislative councils) and difficult to delineate due to uncertain terms and plural office-holding. ${ }^{26}$ The third, related theme was that those courts and their judges

${ }^{21}$ But cf. Russell Wheeler, Extrajudicial Activities of the Early Supreme Court, 1973 Sup. Ct. Rev. 123, 127-30 (arguing that the failure of proposals for a Council of Revision and a Council of State is not inconsistent with an expectation that that the justices would perform some extrajudicial tasks).

${ }^{22}$ The Fourth Provincial Congress of New York had elected John Jay to be Chief Justice of New York's Supreme Court of Adjudicature in 1775, see 1 Documentary History of the Supreme Court of the United States, 1789-1800, pt. 1, at 5 (Maeva Marcus et al. eds., 1985); William Cushing served twelve years on Massachusetts' highest court, first as an Associate Justice of the Massachusetts Superior Court of Judicature, then as its Chief Justice, then continuing as Chief Justice of the successor Supreme Judicial Court, see 1 Documentary History, pt. 1, supra, at 26-27; and John Rutledge was chief judge of South Carolina’s first court of chancery. 1 George J. Lankevich, The Federal Court: 1787-1801, at 239, 243 (1986).

23 The possibility that it did not cohere was noted by Farrand, in comments on Hamilton's proposal.

${ }^{24}$ See Wilfred J. Ritz, Rewriting the History of the Judiciary Act of 1789 at 27, 35-37, 41-44 (1990).

25 See supra note

${ }^{26}$ John Blair, Jr., for example, became Chief Justice of the Virginia General Court in 1779, served as an ex officio member of the first Court of Appeals of Virginia as of its creation in 1779, then was elected as one of the three chancellors of the High Court of Chancery later that year and a member of a supplemental committee of legislative revisors in 1786, before being elected a member of the new Supreme Court of Appeals in 1789 - sometimes holding more than one judicial post at a time, and while serving as a representative to the constitutional convention and to Virginia's ratifying convention. J. Elliot Drinard, John Blair, Jr., 39 Proc. Va. State Bar Ass’n 436, 439 (1927). The powers of the General Court relative to 
were generally subject to political control - only the number of judges, means of initial appointment, and tenure were coming to be fixed by state constitutions ${ }^{27}$ - and details like the appointment of chief justices were often left unresolved. ${ }^{28}$ The Constitution, likewise, guaranteed judges' tenure during “good behavior” and prevented reductions in salary, but without inhibiting Congress from changing the Court's work or the number of justices.

Neither the colonies nor the states had much chance to address how anyone comparable to an associate justice might be promoted to become chief justice, ${ }^{29}$ and the initial experience under the Constitution was a blur. ${ }^{30}$ When President Washington appointed the first slate of justices, he simply designated one, John Jay, as the chief justice. ${ }^{31}$ When Jay resigned to assume the governorship of New York, Washington faced

the High Court of Chancery, to the several courts of appeal, and to the courts of trial jurisdiction - not to mention to the legislature - fluctuated considerably. R.G.H. Kean, Our Judicial System: Some of its History, and Some of its Defects, 1 Rep't of the First Annual Mtng. of the Va. St. Bar Ass'n 139, 142-43 (1889); Francis H. McGuire, The General Court of Virginia, 8 Rep’t of the First Annual Mtng. of the Va. St. Bar Ass'n 197 (1895).

${ }^{27}$ See Martha Andes Ziskind, Judicial Tenure in the American Constitution: English and American Precedents, 1969 Sup. Ct. Rev. 135.

${ }^{28}$ In Virginia, for example, the state constitution of 1776 stated only that the Supreme Court of Appeals should consist of "judges," and the practice evolved of selecting as president the judge with the longest period of continuous service. 2 A.E. Dick Howard, Commentaries on the Constitution of Virginia 727 (1970). Like Virginia, some of the other state constitutions establishing supreme courts or their equivalents did not specify the existence of a chief justice, Maryland Const., Nov. 11, 1776, arts. XLVIII, LVI; New Jersey Const., July 2, 1776, art. XII; New York Const., Apr. 20, 1777, arts. III, XXV, XXXII; North Carolina Const., Dec. 18, 1776, art. XIII; Penn. Const., Sept. 28, 1776, §§ 20, 23, or did so without specifying the means of selection. See Delaware Const., Sept. 21, 1776, art. 12; Georgia Const., Feb. 5, 1777, art. XL. To be sure, a number of state statutes did address the establishment and composition of supreme courts, including an office of chief justice. See Roscoe Pound, Organization of Courts 92-103 (1940). Some judiciary statutes even specified how the chief justice was selected, without providing much detail. But none appear to have immunized the appointment process from legislative change.

${ }^{29}$ John Blair, Jr., as previously noted, had ascended to become the Chief Justice for the Virginia General Court. Under a Virginia law enacted in 1777, judges were to "have precedence in court as they may stand in nomination on the [legislative] ballot, and the person first named shall be called Chief Justice of such court," but the law did not specify how to handle vacancies. McGuire, supra note —, at 203. After Blair's precedessor as chief justice, Joseph Jones, resigned in 1779, Blair appears to have become chief justice - in practice, if not necessarily through formal commission - as the senior-most, second-named judge. See Judge William Brockenrough, Brief Sketch of the Courts of this Commonwealth, 2 Va. Cases 101, 103; Proceedings of March 2, 1778, 2 Journals of the Council of the State of Virginia 95 (noting initial appointments); Personal correspondence from E. Lee Shepard, Director of Manuscripts and Archives, Virginia Historical Society, June 6, 2005 (on file with author). William Cushing, who replaced John Adams as Chief Justice of the Massachusetts Superior Court of Judicature, had been senior Associate Justice beforehand - and acted as Chief Justice in Adams' absence, the latter never having served his appointment. Arthur P. Rugg, William Cushing, 30 Yale L.J. 128, 129-31(1920).

${ }^{30}$ Prior federal experience, needless to say, was not extensive. One example, however, was the Continental Congress' Court of Appeals in Cases of Capture, the presidency of which was apparently selected by lot. 1 Hampton L. Carson, The History of the Supreme Court of the United States 57 (1891).

${ }^{31}$ See 1 Charles Warren, The Supreme Court in United States History 33-36 (1987). John Rutledge, who had left a position as an Associate Justice to take a position as Chief Justice of the South Carolina Court of Common Pleas, later lobbied Washington for the chance to succeed Jay, and his correspondence makes clear that the position as Chief Justice of the Supreme Court was the most prestigious of the three. Id. at 127 (quoting letter from Rutledge to Washington, June 12, 1795); see also 
the first test of how to replace a chief justice. It was a debacle. He first selected former justice John Rutledge, who had left earlier to become a state court judge; Rutledge served briefly with a recess appointment before being rejected by the Senate following a vituperative political speech (against, of all things, the Jay Treaty) that gave rise to rumors that he was mentally unstable. With just weeks before the next sitting, and having lacked a properly confirmed, sitting chief justice for nearly two years, Washington nominated then-Associate Justice William Cushing. The Senate confirmed Cushing the next day - but he resigned his commission one week afterward, on health and age grounds, after serving as chief justice for perhaps one dinner party. Washington finally succeeded with Senator Oliver Ellsworth, though he served only three years as chief justice. $^{32}$

Washington's travails provide only a fleeting and imperfect illustration of how a sitting justice could be promoted, besides signaling some more general problems that would confront choosing chief justices. Attorney General William Bradford, Jr. had opined that the "principle of Rotation would be the least exceptionable" because it reduced the judiciary's dependence on the President, but added that the prospect of an inappropriate senior-most associate justice - he adverted specifically to Justice Cushing made such a system untenable. ${ }^{33}$ The associate justices, on the other hand, expected that one of them would become chief; Thomas Jefferson, writing before Cushing's selection, speculated that the initial Rutledge nomination "seems to have been intended merely to establish a precedent against the descent of that office by seniority, and to keep five mouths always gaping for one sugar plumb. ${ }^{\text {34 }}$ Following the appointment of Cushing, one Federalist worried "that the promotion will form a precedent for making Chief Justices from the eldest Judge though the other candidates may be much better qualified. ${ }^{35}$

Afterward, in fact, a practice developed that no associate justice should be promoted to chief justice. Lincoln and Grant reportedly turned against internal candidates on principle, ${ }^{36}$ and President Cleveland seriously offended Justice Stephen J. Field by looking outside the Court to select Chief Justice Melvin W. Fuller. ${ }^{37}$ President

John Anthony Maltese, The Selling of Supreme Court Nominees 24-25 (1995) (noting newspaper editorials lobbying for and against candidates to be the first Chief Justice).

${ }^{32}$ See James R. Perry, Supreme Court Appointments, 1789-1801: Criteria, Presidential Style, and the Press of Events, 6 J. Early Republic 371, 385-97 (1986).

${ }^{33}$ William Bradford, Jr. to Samuel Bayard, June 4, 1795, in 1 Documentary History of the Supreme Court of the United States, 1789-1800, pt. 2, at 755 (1985). Contrast Tench Coxe to Richard Henry Lee, April 11, 1792, in id. at 735 (noting personal conviction that the office of the Chief Justice, and those of the cabinet secretaries, "should be put on such a footing that when vacant they should unclog'd by the pretensions of any subordinate officer whatever," preferring the "man of first abilities," so that "dull seniority and length of service should be considered as nothing").

${ }^{34} 1$ Warren, supra note _, at 128-29; see 1 Documentary History, supra note _, at 841 (quoting Jefferson to Monroe, letter of March 2, 1796).

${ }^{35} 1$ Warren, supra note _, at 139-40 (quoting letter from Plumer to Smith, Feb. 17, 1796).

${ }^{36}$ Mason, supra note _ , at 51-52. The evidence as to the latter, at least, seems weak; Lincoln appears to have made his selection as a matter of political pragmatism, after giving serious consideration to Justice Swayne. David M. Silver, Lincoln’s Supreme Court 185-209 (1956).

37 James W. Ely, Jr., The Chief Justiceship of Melville W. Fuller, 1888-1910, at 17 (1995); Carl Brent Swisher, Stephen J. Field: Craftsman of the Law 319 (1930). 
Taft, enticing Charles Evans Hughes to consider being associate justice, confided that he did not "regard the practice of never promoting associate justices as one to be followed" (without, he added in a postscript, promising Hughes the promotion outright). ${ }^{38}$ Taft did not actually promote Justice Hughes - and rejected the aspirations of senior Associate Justice John Marshall Harlan, exclaiming that “I won't make the position of chief justice a blue ribbon for the final years of any member of the court”39 - but he did break tradition by nominating a different associate justice, Edward Douglas White. Then-Associate Justice Stone was promoted subsequently (immediately following Chief Justice Hughes, who had been nominated after a period away from the Court), as was Justice Rehnquist. All told - but excluding Justice Cushing - three of the sixteen chief justices who have served to date have resulted from promotion, all of them during this century.

\section{Changing the Chief}

At present, then, a sitting justice may neither count on, nor exclude, the possibility of promotion. While seemingly meritocratic, this uncertainty may also be the worst of both worlds. The reasons for considering promotion are probably self-evident. All things being equal, experience on the Court (to a point) may be helpful in leading it; that is the premise, presumably, of making the senior associate justice the Court's second-incommand, ${ }^{40}$ and the basis for criticisms of inexperienced outsiders. ${ }^{41}$ There are also incentive effects to consider. Diminishing the odds that able associate justices may be considered for chief justice may make it harder to retain them; it is human nature to grow dissatisfied when those less experienced are brought in at higher position, at least where later advancement seems foreclosed. In theory, it may even make it harder to recruit associate justices in the first place - witness Taft's felt need to reassure White in recruiting him to the associate ranks - though it is unlikely to be too dissuasive. ${ }^{42}$

On the other hand, the prospect of promotion may make sitting Justices solicit political favor - something that led former Justice Owen Roberts, later Dean of the University of Pennsylvania Law School, to urge that no that associate justice ought to considered eligible for chief justice. ${ }^{43}$ The specter of political advantage risks relations within the Court as well as the Court's standing. Justice Field's disappointment at losing out was nothing compared to the stunning episode in which Justice Jackson - in a

${ }^{38}$ Quoted in Daniel S. McHargue, Taft’s Supreme Court Appointments, 12 J. Politics 478, 488-89

${ }^{39}$ Quoted in McHargue, supra note _, at 492.

${ }^{40}$ See infra note _. The succession is also traditional in character. Sandra L. Wood, In the Shadow of the Chief: The Role of the Senior Associate Justice, 1997 J. Sup. Ct. Hist. 25.

${ }^{41}$ See, e.g., 1 Merlo J. Pusey, Charles Evans Hughes 278 (1951) (citing criticisms of Chief Justices Waite and Fuller). One may view the same cases differently, of course, see Jeffrey B. Morris, Chief Justice Edward Douglass White and the President Taft's Court, 1982 Yearbook Sup. Ct. Hist. Soc’y 27, 39 (citing Waite and Fuller as comparatively more successful Chief Justices than Edward Douglass White), and there are certainly inexperienced but accomplished Chiefs - such as the Earl Warren.

${ }^{42}$ Cf. Morris, Chief Justice Edward Douglass White, supra note _, at 35 (speculating that had Charles Evans Hughes declined an appointment as Associate Justice, "he probably would have been named Chief Justice”).

${ }^{43}$ Owen J. Roberts, Now is the Time: Fortifying the Supreme Court's Independence, ABA Journal, Jan. 1949, at 1, 2. 
telegram he shared with the public - detailed court feuds in a fury over Justice Black's supposed plotting against Jackson's aspirations for chief justice. ${ }^{44}$ Subsequent charges of presidential cronyism helped to derail the promotion of Justice Fortas and tarnished the Warren Court (though it seems unlikely that Fortas' political activities were intended to advance his judicial career). ${ }^{45}$ The close and continuing relationship many presidents have had with their chief justices - including instances in which chief justices White, Taft, Vinson, Warren, and Burger advised on political matters ${ }^{46}$ - is easily read to suggest a cooperative relationship beforehand as well, undermining the perception of judicial independence.

To bar or discourage promotions, however, is a serious over-correction, at least if the problem stems from the need to have associate justices run the nominations and confirmation gauntlets. Why is it, exactly, that a sitting justice, imbued with life tenure, must be nominated and confirmed anew in order to become chief justice? Clearly, separate appointments are not unconstitutional - the uncontroversial promotions of Justice Cushing and Justice White look like proof positive. If Congress chooses to create a separate office of the chief justice, and to make any would-be occupant subject to confirmation, it is at liberty to do so.

What is less clear, however, is whether promotions need to take this form. Tradition, certainly, would have it so, and deserves some deference. But the relevant tradition is really a longstanding political practice, rather than some purer constitutional understanding, since the practice of separately confirming candidates for chief justice has been over-determined. Prior to the Taft administration - the glancing instance of Cushing aside - separate confirmation was always necessary so that a newcomer could become a "judge" on the Supreme Court. Since the Judiciary Act of 1789 and successor statutes failed to distinguish between internal and external candidates for chief justice, it was inevitable that the rare nomination of a current justice for promotion would be subjected to the same process. The question is open, accordingly, whether a statute might instead differentiate candidates for promotion, and provide for their elevation by some other means - and some possible mechanisms turn out to be surprisingly traditional.

1. A seniority carousel. Presidents have always been able to choose (or avoid) a chief justice based on seniority. But could Congress instead dictate that the senior-most associate justice would automatically serve as chief? The obvious risk would be promoting justices who are past their prime, and unduly encouraging longer service at the Court. Recent work has documented numerous instances of decrepitude on the Supreme Court, and noted the repeated proposals to amend the Constitution in order to establishment a retirement age for justices. ${ }^{47}$

${ }^{44}$ Howard Ball \& Phillip Cooper, Fighting Justices: Hugo L. Black and William O. Douglas and Supreme Court Conflict, 38 Am. J. Legal Hist. 1, 26-27 (1994).

${ }^{45}$ Laura Kalman, Abe Fortas 327-42 (1990).

${ }^{46}$ Fish, supra note _, at 131-33.

${ }^{47}$ See Artemus Ward, Deciding to Leave: The Politics of Retirement from the Supreme Court (2003); David J. Garrow, Mental Decrepitude on the U.S. Supreme Court: The Historical Case for a $28^{\text {th }}$ Amendment, 67 U. Chi. L. Rev. 995 (2000). Garrow criticizes another, slightly more optimistic booklength account, David N. Atkinson, Leaving the Bench: Supreme Court Justices at the End (1999); see also 
Fixing the Supreme Court through a constitutional amendment is not a very likely prospect, whatever its merits, but it would not be required to impose age or term limits on the chief justices - since those are not, after all, addressed in the Constitution. One model is provided by the statute governing the federal courts of appeals, which designates as chief judge the senior-most judge under the age of 65 with at least one year of service and without a prior stint as chief judge - and which limits the term as chief to seven years. $^{48}$ Following suit would plainly limit the age of any associate justice upon promotion, and limit the length of service as chief, but it may also have subtler effects. For example, a seniority carousel may actually reduce the justices' mean age by establishing a natural juncture for exit. A senior associate justice's promotion to chief justice may serve as a nice way of "rounding out" a judicial career (as a disappointed Justice John Marshall Harlan once remarked), ${ }^{49}$ or may find returning to the rank-and-file less than appealing.

Longevity effects aside, such a scheme would diminish the opportunity for strategic behavior by the justices. Predetermining promotion would substantially reduce the incentives that any justice might have for showing favor to those in (or soon to be in) political power. It would also diminish the occasions for alleging such favoritism and, more generally, for the politicized examination of the Court's work. Even assuming that the appointment process is ordinarily constructive, promotions are its least attractive application. Every associate justice was confirmed by the Senate, of course, before joining the Court, and is only spared further review - review of a kind that is more intrusive and less deferential than would have been expected in 1789. Justice Cushing was confirmed only the day after his surprise nomination, and the Senate confirmed the promotions of Justice White and Justice Stone while honoring their position that it would inappropriate for them to testify. ${ }^{50}$ Justice Fortas was not so lucky, nor was Justice Rehnquist - though the Fortas hearings did not uncover the scandal that later drove him from the Court, ${ }^{51}$ and the Rehnquist hearings pretermitted sensitive questions regarding previous ill health. ${ }^{52}$ The virtual certainty that modern sitting justices would be examined on their Supreme Court records poses, at the very least, the risk of reducing the immunity and independence of the Court.

Merlo J. Pusey, The Court Copes with Disability, 1979 Yearbook Sup. Ct. Hist. Soc’y 63 (describing degree to which disability affected the workings of particular courts).

${ }^{48} 28$ U.S.C. $\S 45$. This method is not ubiquitous, and the explanation - if any - is obscure. Compare 28 U.S.C. § 171 (providing for presidential appointment of chief judge of the Court of Federal Claims), with 28 U.S.C. $§ 258$ (providing for seniority-based promotion of chief judge of the Court of International Trade).

${ }^{49}$ Wood, supra note _, at 32.

${ }^{50}$ Kalman, supra note __, at 335 . To the extent that judicial independence was being honored, one would expect nominees from the lower federal courts to equally be respected - as has sometimes been the case. See Charles M. Lamb, Chief Justice Warren E. Burger: A Conservative Chief for Conservative Times, in The Burger Court: Political and Judicial Profiles 132 (Charles M. Lamb \& Stephen C. Halpern eds., 1991) (noting that Burger's testimony during confirmation hearings was short and friendly).

${ }^{51}$ Kalman, supra note _, at 359-76.

${ }^{52}$ Garrow, supra note —, at 1067-69. 
Compared to the alternatives, a seniority-based system doesn't look so bad. ${ }^{53}$ Its main hurdle may be a perceived inconsistency with the Constitution. For one, the President would lose the right of initiative, including in purely tactical respects. The Reagan administration, for example, supposedly demonstrated the wisdom of a risky twonomination strategy: that is, reacting to a vacancy at chief justice by first attempting to promote a controversial (but confirmable) associate justice, then following with a more ideological candidate for the resulting vacancy after the political opposition has been exhausted. $^{54}$ Chief justices can facilitate these or presidential opportunities by timing their resignations, as Chief Justice Warren demonstrated most blatantly in tendering a conditional resignation designed to allow President Johnson (and not Richard Nixon) to choose his replacement. ${ }^{55}$ It is doubtful, though, whether such gambits are constitutionally protected, and their perverseness as a matter of public policy seems selfevident.

A second, weightier objection is that a seniority carousel would reduce the role of both political branches in selecting the next chief justice - not only controlling the selection from among the associate justices, but also excluding the possibility of nominating someone from outside the Court. That complaint has appeal as a matter of public policy, and deserves due consideration, but its constitutional basis is not so strong as to pretermit discussion. While the strongest textual basis for a permanent, separately appointed office of the chief justice is its brief mention in the Impeachment Clause, such an interpretation would unduly cabin legislative authority to regulate the meaning of the "judges" mentioned in Article III. Conceptually, any seniority proposal effectively reconceives all appointments as being to the position of "Justice, eligible for succession to Chief Justice," rather than to the position of “(non-chief) Associate Justice.” In other words, Congress might decide that being chief justice is simply a potential, latent attribute of being a justice, rather than a discrete office requiring political supervision on a piecework basis.

The idea is not as radical as it may sound. As presently structured, the chief justice looks like an "officer" of a kind requiring appointment pursuant to Article II. ${ }^{56}$ But prior cases hold that those already commissioned as officers per the Appointments Clause do not require a separate appointment in order to assume additional duties - thus

${ }^{53}$ Or, as Judge Feinberg once put it, evoking Churchill, "[S]eniority is the worst way to select a chief judge, except for all the other ways.” Wilfred Feinberg, The Office of Chief Judge of a Federal Court of Appeals, 53 Fordham L. Rev. 369, 373 (1984).

${ }^{54}$ Joan Lukey, Beyond Rock, Paper, Scissors: Choosing a New Justice is a Complex Game, Los Angeles Times, Feb. 6, 2005, at 1.

${ }^{55}$ Robert Shogan, A Question of Judgment: The Fortas Case and the Struggle for the Supreme Court 147-48 (1972); Ward, supra note _ , at 171-73. President Johnson responded by accepting the resignation "effective such time as a successor is qualified," and Warren clarified that he would begin serving another term if no successor was qualified by the next October 1. Id. at 152-53. What is more, Robert Shogan speculates that Warren would have guessed that Johnson would nominate Fortas. Id. at 147. See also Ward, supra note _ _ at 177 (indicating that "Justices have for the most part stayed on the bench longer than they should have in order to time their departures to coincide with favorable administrations”).

${ }^{56}$ See, e.g., Freytag v. Commissioner of Internal Revenue, 501 U.S. 868, 881 (1991) (indicating that when a judicial office is “'established by law' . . . and the duties, salary, and means of appointment for that office are specified by statute," individuals occupying that position are likely to be viewed, at a minimum, as “inferior officers” subject to Article II confirmation). 
redeeming the statutory assignment of military officers to be military judges or as part of a commission establishing public parkland - at least so long as those duties are germane to the original office. ${ }^{57}$ The Court's decision upholding the constitutionality of the Sentencing Commission, and its recognition that Congress may subject Article III judges to an additional appointments process before giving them new responsibilities, does not suggest that it must do so, and the Court cited instances in which such responsibilities had been assigned without any such hurdles. ${ }^{58}$ Indeed, the Court cited the chief justice's own ex officio duties, which are an embarrassment to any appointments objection to a seniority carousel; some of these assignments, like the chief justice's inclusion in the Sinking Funds Commission in 1806, are deeply rooted in the constitutional tradition, and were not regarded as raising Appointments Clause problems. ${ }^{59}$ Any constitutional infirmity would also seemingly call into question the statute designating chief judges for the courts of appeal, which must be premised on the distinction between the tenure of a federal judge and the tenure of his or her stint as chief judge.

One might insist, again, that the express constitutional mention of the chief justice (and not, say, the chief judge of the D.C. Circuit) makes all the difference. This could be resolved by retaining a "Chief Justice," selected as at present, to do the only thing mentioned in the Constitution - preside over impeachment of the president - and creating a different officer (say, the "Principal Justice"), selected on seniority, to discharge all the chief's other tasks. Even doing that would do more than the Impeachment Clause requires. The framers didn't designate the chief justice in order to avoid having other members of the Supreme Court preside; the idea, presumably, was to designate a definite member of the brethren in lieu of the vice president, who otherwise might affect whether he or she would succeed to the presidency. ${ }^{60}$ (If anything, the Clause's general theme to reduce the role of executive branch politics in the impeachment process - would favor employing a justice selected without presidential intervention.) Finally, if the Impeachment Clause means that only a person confirmed as chief justice will do, it would condemn the existing law that allows the senior associate justice to serve if and to the extent that the chief justice becomes disabled. ${ }^{61}$ Whatever the merits of the present scheme, and however steeped in tradition it may be, it simply cannot be defended as a constitutional necessity.

2. A College of Cardinals. Once liberated from the confirmation process, the chief justice may be selected from among the sitting justices in a number of ways, not just by seniority. For example, a statute could provide that the justices themselves could

${ }^{57}$ Weiss v. United States, 510 U.S. 163, 169-76 (1994); Shoemaker v. United States, 147 U.S. 282, 300-01 (1893)

${ }^{58}$ Mistretta v. United States, 488 U.S. 361 (1989).

${ }^{59}$ Wheeler, supra, at 139-44. See also 15 Annals of Cong. 929 (1806) (remarks of John Randolph) (suggesting that commissioners on the Sinking Fund Commission "are not, strictly speaking, officers," since "[t]he duties they discharge are ex officio ... and, as Commissioners, they receive no salary").

${ }^{60}$ Letter from Chief Justice Salmon P. Chase, March 4, 1868, Senate Journal, March 4, 1868, at 798-99.

${ }^{61} 28$ U.S.C. § 3 ("Whenever the Chief Justice is unable to perform the duties of his office or the office is vacant, his powers and duties shall devolve upon the associate justice next in precedence who is able to act, until such disability is removed or another Chief Justice is appointed and duly qualified.”). 
elect their chief, not unlike the way the College of Cardinals chooses the Pope (though the Pope, it turns out, need not have been a Cardinal). ${ }^{62}$

Like the seniority carousel, such an approach has legal antecedents. The state of Florida, for example, lets a majority of its justices decide on the chief justice - by tradition, for a two-year term. ${ }^{63}$ The consistency with the federal constitution is less clear, certainly, of course, but still compelling. Under Article II, § 2, Congress is free to "vest the Appointment of such inferior Officers, as they think proper" in, among others, "the Courts of Law." Accordingly, the Supreme Court has held, the chief judge of the U.S. Tax Court, acting as one of those "Courts of Law" despite its non-Article III status, may be statutorily assigned the power to appoint special trial judges exercising substantial discretion, including by deciding certain cases and hearing and proposing findings in others. ${ }^{64}$ By comparison, vesting an entire Article III court with the power to select a chief justice from among the justices seems unexceptionable, so long as the statute clearly distinguishes between the additional duties of a chief justice and the powers that individual already possesses as a duly confirmed associate justice.

A College of Cardinals would also reflect the reality that the Court is substantially self-regulating. Permitting the chief justice to assign opinions, for example, is just a longstanding practice; by tradition, of course, chief justices exert substantial power, but any threat that they would unilaterally upend other traditions risks a fierce backlash, at least by the Court's mavericks. ${ }^{65}$ This self-regulation has, in fact, sometimes touched on questions of tenure. Justices have advised their colleagues when they are too old to continue serving, ${ }^{66}$ or on occasion, conspired to deprive them of their full authority usually in limiting opinion-writing assignments, but also when the colleagues of Justice McKenna and Justice Douglas decided that neither of them should cast deciding votes. ${ }^{67}$ Sitting and departing justices have also advised presidents regarding the best choice for a successor chief justice. ${ }^{68}$

${ }^{62}$ Interestingly, John Paul II regarded it as "an indisputable principle that the Roman Pontiff has the right to define and adapt to changing times the manner of designating the person called to assume the Petrine succession in the Roman See.” John Paul II, Apostolic Constitution: Universi Dominici Gregis, On the Vacancy of the Apostolic See and the Election of the Roman Pontiff, Feb. 2, 1996,

http://www.vatican.va/holy_father/john_paul_ii/apost_constitutions/documents/hf_jpii_apc_22021996_universi-dominici-gregis_en.html. So why not the Chief Justice?

${ }^{63}$ Joseph A. Boyd, Jr., \& Randall Reder, A History of the Florida Supreme Court, 35 U. Mia. L. 1019, 1024, 1040-41, 1051 (1981); see Rev. Fla. Const. art. 5, § 2; Fla. R. Jud. Admin., Rule 2.030.

${ }^{64}$ Freytag v. Commissioner of Internal Revenue, 501 U.S. 868 (1991).

${ }^{65}$ Justice Douglas, for example, objected vigorously when he perceived that Chief Justice Burger was usurping the right of the senior associate justice in the majority to make the opinion assignment if the chief justice was dissenting. Wood, supra note _, at 29-30. Justice McReynolds, in an earlier episode, supposedly told a messenger sent by Chief Justice Hughes, “Tell the Chief Justice that I don't work for him.” Steamer, supra note _, at 21.

${ }^{66}$ E.g., with Justices Grier, Field, Justice McKenna, and Justice Holmes. Garrow, supra note at 1004-05, 1009, 1014-16, 1017-18.

${ }^{67}$ Garrow, supra note _, at 1015, 1054-56; Ward, supra note _, at 116-19, 186-89. Garrow and Ward also report that Justice Rutledge (and possibly Justice Black) cast votes for an ailing Justice Murphy. Garrow, supra note _, at 1027; Ward, supra note _, at 148.

${ }^{68}$ Ward, supra note _, at 170 (noting advice rendered by Warren regarding his successor); Paul A. Freund, Charles Evans Hughes as Chief Justice, 81 Harv. L. Rev. 4, 7 \& n.10, 8 (1967) (noting 
Assigning the justices responsibility for electing a chief justice would be somewhat more transparent. It is also more facile. As then-Justice Rehnquist admitted, judges have a tendency toward "pulling the wagons around" when it comes to matters of their health and competence; ${ }^{69}$ this reticence mainly marks their willingness to share infirmities with the outside world, but it may also account for their tardiness in confronting colleagues with the need to retire. ${ }^{70}$ No justice, moreover, needs to accept such advice. ${ }^{71}$ Allowing the justices to determine their leader makes intervening on the basis of age and health easier: not only is demotion less of a bitter pill than resignation, but the justices' action as to the status of a chief justice could be decisive rather than merely advisory. Judges have long recognized, in principle, the problem of decrepitude Charles Evans Hughes, between spells on the Court, urged a mandatory retirement policy, and Judge Richard Posner, limited to a term as chief judge, described the judiciary as "the nation's premier geriatric occupation"72 - and might be given better tools with which to help themselves.

\section{Conclusion}

Needless to say, upsetting the scheme for chief justices after over 200 years is no mean feat, and less ambitious changes may be better. A compromise would be to combine a promotion mechanism with more traditional avenues for appointment. A statute might provide, for example, that the president may nominate any candidate for chief justice, but that if he or she does not - or if no candidate is confirmed - a specified promotion mechanism would kick in (yielding, for example, the promotion of the seniormost associate justice for a term of years). Better still, the statute might defer to a statutory promotion mechanism unless and until the president overrode that chief justice with a separately nominated candidate ... having convinced the Senate that the new candidate was superior to the incumbent. Either method seems hard to criticize, particularly since existing law provides that the senior associate justice may serve in lieu of the chief justice - without even the safeguard of a limited term. ${ }^{73}$ Each would also allow nomination of a newcomer as chief justice, which may be a necessary alternative in case of an aging or dysfunctional court. If the political branches genuinely feared losing

consultations prior to nomination of Hughes and Stone); McHargue, supra note $\longrightarrow$, at 492 (consultations prior to nomination of Justice White); Morris, Chief Justice Edward Douglass White, supra note _, at 3336 (same).

${ }^{69}$ Nomination of Justice William Hubbs Rehnquist, Hearings before the Committee on the Judiciary, United States Senate, on the Nomination of Justice William Hubbs Rehnquist to be Chief Justice of the United States, 99th Cong, 2d Sess 206 (July 29-31 and Aug 1, 1986).

${ }^{70}$ Garrow's article is essentially a criticism of prior opinion that the practice of collegial intervention was sufficient. Garrow, supra note _, at 1082-85.

${ }^{71}$ According to one well-known anecdote, Justice Harlan was sent to ask an aging Justice Field if he recalled his own intercession with Justice Grier some years before. Justice Field replied, "Yes! And a dirtier day's work I never did in my life!” Charles Evans Hughes, The Supreme Court of the United States 76 (1936).

${ }^{72}$ Quoted in Garrow, supra note _ at 997-98.

${ }^{73} 28$ U.S.C. § 3 (quoted supra). Some instances in which this happened, none appearing to have exceeded six months, are noted in Wood, supra note _ , at 26-29. 
control of the Court, they could always compensate by diminishing the chief justice's statutory responsibilities.

In any event, the time is propitious for reconsidering the chief justice. Chief Justice Rehnquist recently presided over only the second impeachment of a president, receiving good marks; at this small remove, it is easy to see how only good fortune prevented the trial from being marred by allegations of favoritism. (Imagine how many would have protested if President Clinton's successful defense had been presided over by a Clinton-selected chief justice, or if Chief Justice Rehnquist had taken debatable positions that resulted in the president's removal.) Recent debates over the filibuster have showed the persistence of ideological rifts over judicial appointments, boding ill for future nominations to the Supreme Court. The average age of the justices, which exceeds 70 , not only makes appointments battles seem imminent, but also highlights the value of appointing a new chief justice with the experience and standing to lead them. If we desire constructive, rather than destructive, political dialogue over the choice of a chief justice, it is better to do so systematically - including by considering the proper method for choosing, and not just the individuals as they arise. 